\title{
44. ORGANIC FACIES OF CENOZOIC AND CRETACEOUS SEDIMENTS FROM DEEP SEA DRILLING PROJECT SITES 548 TO 551, NORTHERN NORTH ATLANTIC1
}

\author{
Robert Cunningham and Deborah Gilbert, Exxon Production Research Company, Houston²
}

\begin{abstract}
The organic facies of Cenozoic sediments cored at DSDP Sites 548-551 along the Celtic Sea margin of the northern North Atlantic (Goban Spur) is dominated by terrestrially derived plant remains and charcoal. Similar organic facies also occur in the Lower and Upper Cretaceous sections at these sites. Mid-Cretaceous (uppermost Albian-Turonian) sediments at Sites 549-551, however, record two different periods of enrichment in organic material, wherein marine organic matter was mixed with terrestrial components. The earlier period is represented only in the uppermost Albianmiddle Cenomanian section at the most seaward site, 550 . Here, dark laminated marly chalks rich in organic matter occur rhythmically interbedded with light-colored, bioturbated marly chalks poor in organic matter, suggesting that bottom waters alternated between oxidizing and reducing conditions. A later period of enrichment in organic material is recorded in the upper Cenomanian-Turonian sections at Sites 549 and 551 as a single, laminated black mudstone interval containing biogenic siliceous debris. It was deposited along the margin during a time of oxygen deficiency associated with upwelling-induced intensification and expansion of the mid-water oxygen-minimum layer. In both the earlier and later events, variations in productivity appear to have been the immediate cause of oxygen depletion in the bottom waters.
\end{abstract}

\section{INTRODUCTION}

One of the objectives of Leg 80 of the Deep Sea Drilling Project was to determine the effects of changing paleoceanographic conditions on the accumulation, composition, and diagenesis of sediments on the Goban Spur and the adjacent Porcupine Abyssal Plain along the Southern Irish continental margin (Fig. 1). Among the more useful sedimentary parameters to monitor when conducting such a study are the types and amounts of organic matter. Organic matter is a sensitive indicator of (1) the degree of oxygenation of bottom waters, because more labile components are better preserved under less oxic conditions, (2) surface water productivity, because enrichment in organic matter may coincide with high productivity, and (3) the paleoclimate of the hinterland (humid vs. arid), because runoff affects the supply of terrestrial organic matter to the depositional environment.

Of particular paleoceanographic significance are the black chalks and mudstones that occur in the uppermost Albian to Turonian sections at Sites 549, 550, and 551 . These sequences are enriched in marine-derived organic matter and appear to have been deposited during two different periods of bottom-water oxygen depletion. The older sequence, uppermost Albian (Vraconian) to middle Cenomanian, was found only at the most seaward (and deepest) site, 550 (Fig. 1). It is made up of interbedded light-colored, bioturbated, and darker (often black) laminated, marly chalks and calcareous mudstones. Darker intervals are enriched in organic matter, whereas lighter intervals are lean in such matter. A later

\footnotetext{
${ }^{1}$ Graciansky, P. C. de, Poag, C. W., et al., Init. Repts. DSDP, 80: Washington (U.S. Govt, Printing Office).

2 Address: Exxon Production Research Co., P.O. Box 2189, Houston, TX 77001.
}

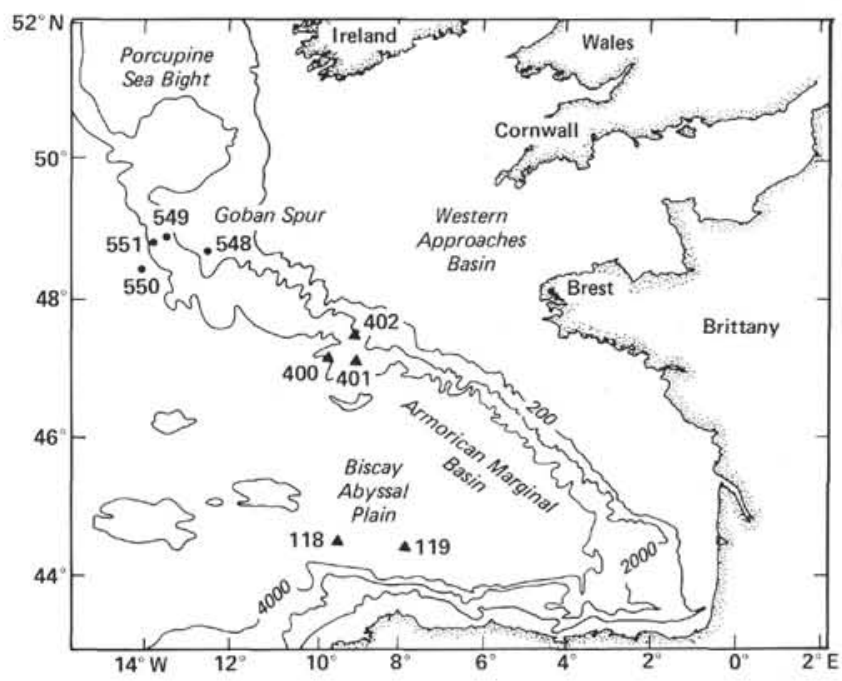

Figure 1. Locations of DSDP Sites 548-551. Bathymetry in meters. Previous DSDP drill sites in the region $(118,119$, and $400-402)$ are included for reference.

period of oxygen depletion is inferred from a recovered single interval of black mudstone rich in organic matter (upper Cenomanian or lower Turonian) at Sites 549 and 551 .

To determine the relative importance of such effects as productivity, preservation, and climate on deposition of organic matter at Sites 548-551 during the Cenozoic and Cretaceous, we have examined the types and amounts of organic matter in the sediments. The findings for the mid-Cretaceous were related to the deposition of organic matter in coeval sediments at other sites in the northern North Atlantic to determine the regional controls on organic facies and content of organic matter. 


\section{METHODS}

Analyses for type and amount of organic matter were conducted on the Cenozoic and Cretaceous lithologic units of Sites 548-551. The types of organic matter were characterized using transmitted-light microscopy (Masran, 1978; Masran and Pocock, 1981), Rock-Eval pyrolysis (Espitalié et al., 1977), and lipid extraction followed by capillary gas chromatography; total organic carbon (TOC) was determined by LECO combustion. Our TOC and pyrolysis data supplement the extensive shipboard analyses conducted by Waples and Cunningham (this volume); for individual lithologic units we report average values for TOC and pyrolysis based on the results of this study and the shipboard data.

\section{RESULTS}

\section{Types and Amounts of Organic Matter}

\section{Site $\mathbf{5 4 8}$}

The Holocene to Upper Cretaceous post-rift sediments recovered at Site 548 (1246 m water depth), the shallowest and most shoreward of the Goban Spur transect sites (Fig. 1), generally contain low levels of organic matter. On average, the total organic carbon (TOC) content decreases from $0.40 \%$ in lithologic Subunit 1a to $0.08 \%$ in Unit 6 (Table 1; Fig. 2).

Terrestrial components (wood and charcoal) constitute, on average, $75 \%$ of the particulate organic matter in the Site 548 samples (Table 1). A minor contribution of amorphous and algal material (generally less than $30 \%$ ) is apparent in some samples from each of the units studied, and a sizable fraction of indeterminate fine material (av. 50\%) occurs in Units 3 to 5. Pyrolysis data indicate a predominantly terrestrial origin for the organic matter at this site. Hydrogen indices are usually less than $150 \mathrm{mg}$ hydrocarbons (HC)/g TOC; oxygen indices are usually greater than $150 \mathrm{mg} \mathrm{CO} / \mathrm{g}$ TOC for samples from all units (Table 1). Values such as these indicate terrestrial and (or) highly oxidized organic matter generally referred to as Type III kerogen-based on the Van Krevelen-type diagram developed by Espitalié et al. (1977; see Fig. 3 of this paper for reference). The predominance of terrestrial organic matter, general lack of enrichment in organic material, and intense bioturbation throughout the sequence indicate that oxidizing conditions have existed at Site 548 since the Campanian.

\section{Site 549}

The Holocene to Barremian post- and syn-rift sediments recovered at Site 549 ( $2535 \mathrm{~m}$ water depth) show two periods of enrichment in organic matter, one represented in Unit 10 (lower Barremian) and the other in Unit 5 (lower Cenomanian to Turonian) (Table 1; Fig. 2 ). The other lithologic units contain only minor amounts of organic matter. The predominantly nannofossil oozes and chalks making up Units 1-4 average $0.06-0.27 \%$ TOC. Although chalks poor in organic matter make up the bulk of Unit 5, an upper Cenomanian-Turonian black siliceous mudstone very rich in organic matter (up to $9.31 \%$ TOC) occurs in Section 54927-1. The TOC contents of Units 6 to 9 are again low, averaging only $0.31-0.40 \%$ TOC. In Unit 10 , however,
TOC values average $1.00 \%$ and range up to $6.87 \%$. The carbonate content of these sediments decreases toward the bottom of the hole as a result of the increasing influence of terrigenous clastic input on sedimentation.

The black siliceous mudstone interval in Core 27 of Unit 5 represents one of the few periods when marine organic matter accumulated in the sediments recovered on Leg 80 . The bulk of the kerogen is made up of amorphous material (av. 60\%); woody, coaly, and indeterminate fine material make up the remainder (Table 1). Relatively high hydrogen indices, up to $459 \mathrm{mg} \mathrm{HC} / \mathrm{g} \mathrm{TOC}$, indicate a marine origin for the amorphous kerogen. Marine-derived kerogen is richer in hydrogen than Type III organic matter, and plots in the Type II field on the Van Krevelen-type diagram (Fig. 3; Espitalié et al., 1977). Only terrestrial organic matter was observed by pyrolysis and visual kerogen analysis to occur in the other units at Site 549.

During most of the depositional history at Site 549, bottom waters appear to have been well oxygenated. This is supported by the intense burrow mottling, low contents of TOC, and lack of marine organic matter in the sediments. Although some intervals in Unit 10 are enriched in organic matter, they are bioturbated and contain only terrestrial kerogen, suggesting that oxidizing conditions existed at the times they represent as well. In Section 549-27-1, however, the presence of a finely laminated black mudstone interval (uppermost Cenomanian to lower Turonian) enriched in marine organic matter indicates that the bottom waters were briefly reducing.

\section{Site $\mathbf{5 5 0}$}

Site 550 (4432 $\mathrm{m}$ water depth) is the deepest and most seaward site on the Goban Spur transect (Fig. 1). All the lithologic units (Fig. 2; Table 1) were deposited at either abyssal (Units 1-3) or bathyal depths (Units 4 and 5) (de Graciansky et al., this volume). The nannofossil oozes, chalks, and calcareous mudstones from Subunit 1a to Subunit 3b (lower Paleocene to Campanian) are uniformly low in content of organic matter, with TOC values averaging from $0.05 \%$ to $0.09 \%$. The Coniacian to Santonian black claystones and interbedded mudstones and turbiditic nannofossil chalks of Subunits $4 \mathrm{a}$ and $4 \mathrm{~b}$ have average TOC values of $0.35 \%$ and $0.28 \%$, respectively, slightly higher than the shallower units. The low $\mathrm{CaCO}_{3}$ content $(0-10 \%)$ of the claystones and mudstones suggests that the CCD was much shallower during deposition of this unit than for the overlying and underlying units (de Graciansky et al., this volume). In Unit 5, finely laminated marls and calcareous mudstones, both rich in organic matter (av. 1.27\% TOC), are rhythmically interbedded with uppermost Albian (Vraconian) to middle Cenomanian nannofossil chalks poor in organic matter (av. $0.17 \%$ TOC).

Kerogen description and pyrolysis results show that most units at Site 550 contain a terrestrial organic facies (Table 1 and Fig. 3). In Unit 5, however, the laminated intervals rich in organic matter have moderate hydrogen indices (av. $206 \mathrm{mg} \mathrm{HC} / \mathrm{g} \mathrm{TOC}$ ), indicating a mixture of Type II (marine) and Type III (terrestrial) organic mat- 
Table $1 . \mathrm{CaCO}_{3}$ and TOC contents (\%), contents of organic matter by type (\%), thermal alteration indices (TAI), and pyrolysis data, DSDP Sites 548-551.

\begin{tabular}{|c|c|c|c|c|c|c|c|c|c|c|c|c|c|c|c|c|}
\hline \multirow[b]{2}{*}{ Unit } & \multirow{2}{*}{$\begin{array}{c}\text { Sample } \\
\text { (interval in } \mathrm{cm} \text { ) }\end{array}$} & \multirow{2}{*}{$\begin{array}{l}\text { Sub-bottom } \\
\text { depth } \\
\text { (m) }\end{array}$} & \multirow{2}{*}{$\begin{array}{l}\text { Chrono- } \\
\text { stratigraphy }\end{array}$} & \multirow[b]{2}{*}{$\mathrm{CaCO}_{3}$} & \multirow[b]{2}{*}{ TOC } & \multicolumn{7}{|c|}{ Type of organic matter } & \multirow[b]{2}{*}{ TAI } & \multirow[b]{2}{*}{$\mathrm{HI}$} & \multirow[b]{2}{*}{ OI } & \multirow{2}{*}{$\begin{array}{l}T_{\max } \\
\left({ }^{\circ} \mathrm{C}\right)\end{array}$} \\
\hline & & & & & & Am & $\mathrm{Al}$ & PS & w & $\mathrm{C}$ & IF & Other & & & & \\
\hline Ia & $1-2,54-56$ & 2.1 & Pleist. & 18.2 & 0.40 & - & - & 20 & 60 & 20 & - & - & 1.5 & 67 & 1130 & - \\
\hline la & $3-2,60-73$ & 15.7 & Pleist. & 22.6 & 0.53 & 90 & - & - & 10 & - & - & - & - & 84 & 832 & - \\
\hline la & $5-2,0-15$ & 34.1 & Pleist. & 36.1 & 0.35 & 30 & - & 10 & 40 & 20 & - & - & 1.7 & - & - & - \\
\hline 2 & $7-2,60-76$ & 53.7 & Pleist. & 21.4 & 1.23 & - & - & 10 & 80 & 10 & - & - & 1.7 & 86 & 628 & 420 \\
\hline 2 & $13-2,70-85$ & 93.3 & Pleist. & 18.1 & 0.45 & 10 & - & - & 10 & 80 & - & - & 2.0 & - & - & - \\
\hline 3 & $15-2,48-62$ & 102.1 & Pleist. & 28.4 & 0.35 & 30 & - & - & 20 & 50 & - & - & 1.9 & 82 & 982 & - \\
\hline 3 & $17-4,75-89$ & 123.3 & u. Pleist. & 41.3 & 0.41 & - & - & - & 40 & - & 60 & - & 1.9 & 129 & 948 & - \\
\hline 3 & $19-2,37-47$ & 132.9 & u. Pleist. & 48.4 & 0.35 & - & - & - & 30 & 20 & 50 & - & 1.9 & - & - & - \\
\hline 3 & $23-2,125-139$ & 153.8 & u. Pleist. & 50.9 & 0.30 & - & - & - & 10 & 10 & 80 & - & - & - & - & - \\
\hline 3 & $25-2,130-145$ & 163.9 & u. Pleist. & 42.2 & 0.24 & - & 20 & - & 30 & 20 & 30 & - & 2.0 & 137 & 1270 & - \\
\hline 3 & $27-2,94-107$ & 173.5 & 1. Pleist. & 49.5 & 0.28 & - & - & - & 20 & 40 & 40 & - & 2.0 & - & - & - \\
\hline 3 & $29-2,65-79$ & 183.2 & 1. Pleist. & 63.2 & 0.29 & - & - & - & 10 & so & 40 & - & 2.0 & - & - & - \\
\hline 3 & $31-2,64-79$ & 193.2 & I. Pleist. & 60.8 & 0.14 & - & - & - & 10 & 60 & 30 & - & 2.0 & - & - & - \\
\hline 3 & $33-2,63-77$ & 204.7 & I. Pleist. & 57.8 & 0.20 & - & 10 & - & 10 & 60 & 20 & - & 2.0 & 160 & 1440 & 400 \\
\hline 3 & $35-1,70-85$ & 209.8 & 1. Pleist. & 53.7 & 0.20 & - & - & - & 10 & 60 & 30 & - & 1.9 & - & - & - \\
\hline
\end{tabular}

Hole 548A

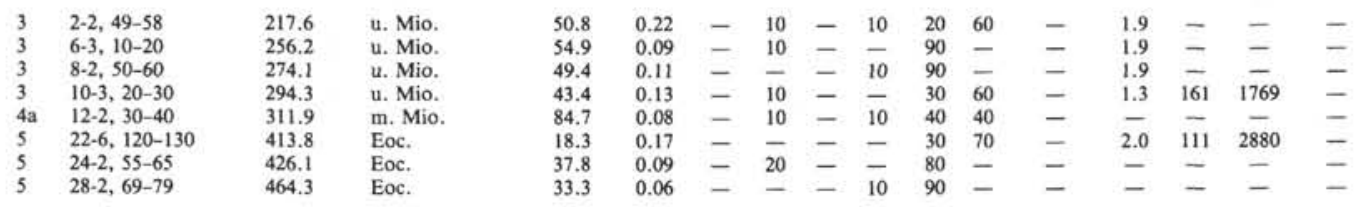

Hole 549

\begin{tabular}{|c|c|c|c|c|c|c|c|c|c|c|c|c|c|c|c|c|}
\hline 4 & $22-2,99-105$ & 391.0 & Maest. & 78.8 & 0.01 & - & - & - & 10 & 90 & - & - & - & - & - & - \\
\hline 5 & $27-1,40-43$ & 436.4 & Cenom.-Tur. & 25.0 & 9.31 & 70 & - & - & 10 & 10 & 10 & - & 2.0 & 459 & 90 & 409 \\
\hline 5 & $27-1,43-46$ & 436.5 & Cenom.-Tur. & 1.5 & 2.09 & 50 & - & - & 10 & 10 & 30 & - & 2.2 & 212 & 134 & 424 \\
\hline 6 & $35-1,67-74$ & 512.7 & m. Alb. & 26.8 & 0.22 & - & - & - & 20 & 80 & - & - & 2.0 & - & - & - \\
\hline 6 & $37-1,67-73$ & 523.2 & m. Alb. & 27.3 & 0.47 & - & - & 10 & 30 & 60 & - & - & 1.7 & - & - & - \\
\hline 6 & $42-2,39-46$ & 570.9 & m. Alb. & 62.0 & 0.34 & - & - & 10 & 30 & 60 & - & - & 2.0 & - & - & - \\
\hline 6 & $44-1,38-51$ & 588.5 & m. Alb. & 28.3 & 0.52 & - & - & 10 & 40 & 40 & 10 & - & 2.0 & - & - & - \\
\hline 6 & $46-2,115-121$ & 609.7 & m. Alb. & 73.6 & 0.11 & - & - & - & 30 & 70 & - & - & 2.0 & - & - & - \\
\hline 7 & $52-1,6-8$ & 664.1 & u. Barrem. & 77.8 & 0.09 & - & - & - & 40 & 60 & - & - & 2.0 & - & - & - \\
\hline 8 & $57-2,120-132$ & 712.8 & 1. Barrem. & 32.2 & 0.16 & - & - & - & 60 & 40 & - & - & 2.0 & - & - & - \\
\hline 8 & $59-2,46-53$ & 730.0 & I. Barrem. & 13.9 & 0.33 & - & - & - & so & 50 & - & - & 2.0 & - & - & - \\
\hline 8 & $60-2,36-50$ & 738.9 & 1. Barrem. & 38.1 & 0.25 & - & - & - & 50 & 50 & - & - & 1.7 & - & - & - \\
\hline 10 & $72-1,95-100$ & 802.5 & 1. Barrem. & 39.3 & 0.70 & - & - & - & 50 & 30 & 20 & - & 2.0 & - & - & - \\
\hline 10 & $74-2,10-19$ & 812.7 & 1. Barrem. & 60.3 & 0.09 & - & - & - & 50 & 50 & - & - & 2.0 & - & - & - \\
\hline 10 & $76-2,37-47$ & 826.9 & I. Barrem. & 8.4 & 0.83 & - & - & - & 60 & 20 & 20 & - & 2.0 & - & - & - \\
\hline 10 & $79-1,76-79$ & 852.8 & 1. Barrem. & 2.5 & 0.52 & - & - & - & 40 & 60 & - & - & 1.7 & - & - & - \\
\hline 10 & $84-2,66-76$ & 886.2 & I. Barrem. & 0.2 & 0.16 & - & - & - & 60 & 40 & - & - & - & - & - & - \\
\hline 10 & $85-2,127-137$ & 890.8 & 1. Barrem. & 4.2 & 2.80 & - & - & 10 & 70 & 10 & - & $10(\mathrm{BT})$ & 1.7 & 137 & 121 & 427 \\
\hline 10 & $88-2,27-37$ & 910.8 & I. Barrem. & 0.1 & 0.07 & - & - & - & 70 & 30 & - & - & 2.0 & - & - & - \\
\hline 10 & $90-2,117-130$ & 931.2 & 1. Barrem. & 5.7 & 0.24 & - & - & - & 70 & 30 & - & - & 2.0 & - & - & - \\
\hline 10 & $91-2,12-20$ & 939.2 & I. Barrem. & 5.4 & 0.61 & - & - & - & 50 & 30 & - & - & 2.0 & 67 & 280 & 422 \\
\hline 10 & $92-1,80-83$ & 947.3 & 1. Barrem. & 7.8 & 6.87 & - & - & 10 & 50 & 20 & - & $20(\mathrm{BT})$ & 2.0 & 128 & 83 & 407 \\
\hline \multicolumn{17}{|c|}{ Hole 550} \\
\hline 1 & $1-2,30-34$ & 1.8 & Pleist. & 27.1 & 0.29 & - & - & - & 80 & 10 & - & $10(\mathrm{BT})$ & 2.0 & - & - & - \\
\hline la & $5-2,90-103$ & 130.5 & 1. Pleist. & 78.7 & 0.08 & - & - & - & 40 & 60 & - & - & - & - & - & - \\
\hline \multicolumn{17}{|c|}{ Hole 550B } \\
\hline $3 a$ & $6-5,90-100$ & 529.5 & Maest. & 42.9 & 0.05 & - & - & - & - & 100 & - & - & - & - & - & - \\
\hline $3 b$ & $12-4,67-74$ & 565.7 & Camp. & 56.9 & 0.03 & - & - & - & 80 & 20 & - & - & - & - & - & - \\
\hline $4 a$ & $13-6,45-56$ & 578.0 & Coniac.-Sant. & 0.6 & 0.55 & - & - & - & 60 & 40 & - & - & 2.0 & - & - & - \\
\hline 5 & $16-1,98-102$ & 599.5 & m. Cenom. & 80.3 & 1.54 & 40 & - & - & 10 & 30 & 20 & - & 2.2 & 214 & 215 & 427 \\
\hline 5 & $16-2,101-102$ & 601.0 & m. Cenom. & 73.8 & 1.98 & 30 & - & - & 10 & 40 & 20 & - & 2.3 & 250 & 160 & 421 \\
\hline 5 & $16-2,146-148$ & 601.5 & m. Cenom. & 21.9 & 0.99 & 10 & - & 10 & 20 & 60 & - & - & 2.0 & 108 & 251 & 427 \\
\hline 5 & $17-2,0-10$ & 608.1 & m. Cenom. & 64.7 & 0.06 & - & - & - & 10 & 90 & - & - & - & - & - & - \\
\hline 5 & $17-2,74-80$ & 610.3 & m. Cenom. & 67.4 & 2.37 & 40 & - & - & 30 & 20 & 10 & - & 1.9 & 284 & 137 & 424 \\
\hline 5 & $17-2,110-115$ & 610.6 & m. Cenom. & 67.7 & 2.26 & 30 & - & - & 40 & 20 & 10 & - & 2.3 & 286 & 148 & 422 \\
\hline 5 & $17-3,108-110$ & 612.1 & m. Cenom. & 76.3 & 1.72 & 20 & - & 10 & 40 & 20 & 10 & - & 2.0 & 269 & 164 & 423 \\
\hline 5 & $18-1,6-10$ & 617.1 & m. Cenom. & 71.1 & 2.19 & 30 & - & 10 & 30 & 20 & 10 & - & 2.2 & 313 & 166 & 422 \\
\hline 5 & $18-1,41-45$ & 617.2 & m. Cenom. & 66.4 & 1.86 & 30 & - & - & 30 & 30 & 10 & - & 2.2 & 253 & 165 & 428 \\
\hline 5 & $20-3,30-45$ & 638.4 & I. Cenom. & 52.5 & 0.98 & - & - & - & 20 & 40 & 40 & - & 1.7 & 61 & 295 & 430 \\
\hline 5 & $23-4,20-26$ & 666.7 & u. Alb. & 60.5 & 1.58 & 20 & - & - & 20 & 20 & 20 & $20(R B)$ & 2.3 & 186 & 181 & 430 \\
\hline 5 & $23-4,57-72$ & 667.2 & u. Alb. & 51.1 & 0.27 & 10 & - & - & 70 & 20 & - & - & 2.3 & 18 & 1196 & - \\
\hline 5 & $24-2,46-49$ & 673.0 & u. Alb. & 52.0 & 2.02 & 20 & - & - & 20 & 20 & 20 & 20 (RB) & 2.3 & 215 & 203 & 428 \\
\hline 5 & $24-2,55-59$ & 673.1 & u. Alb. & 55.7 & 1.68 & 20 & - & 10 & 20 & 40 & - & $10(\mathrm{RB})$ & 2.3 & 146 & 208 & 430 \\
\hline 5 & $25-2,97-107$ & 682.5 & u. Alb. & 58.4 & 0.95 & 10 & - & 10 & 60 & 10 & 10 & - & 2.3 & 54 & 296 & 426 \\
\hline 5 & $25-2,137-143$ & 683.0 & u. Alb. & 55.9 & 1.91 & 20 & - & 10 & 30 & 30 & - & 10 (RB) & 2.0 & 223 & 187 & 424 \\
\hline 5 & $25-3,60-68$ & 683.6 & u. Alb. & 68.6 & 1.69 & - & 40 & - & 10 & 20 & 30 & - & 2.0 & 235 & 173 & 427 \\
\hline 5 & $25-4,56-65$ & 685.1 & u. Alb. & 48.2 & 0.38 & - & - & - & 30 & 70 & - & - & 2.0 & 18 & 823 & - \\
\hline
\end{tabular}

Hole 551

\begin{tabular}{llrllllllllllllll}
2 & H1-1, 100-111 & 48.1 & Eoc. & 14.8 & 0.30 & - & - & - & 50 & 50 & - & - & 2.1 & 110 & 1250 & - \\
5 & $5-2,67-70$ & 134.7 & Cenom.-Tur. & 1.3 & 6.24 & 30 & $=$ & - & 10 & 10 & 30 & $20(\mathrm{BT})$ & 1.8 & 374 & 107 & 415 \\
5 & $5-2,103-112$ & 135.1 & Cenom.-Tur. & 2.3 & 6.66 & 20 & - & - & 20 & 10 & 50 & - & 1.9 & 368 & 90 & 411 \\
\hline
\end{tabular}

Note: $\% \mathrm{CaCO}_{3}$ was calculated assuming that all inorganic carbon occurs as $\mathrm{CaCO}_{3}:$ total organic and inorganic carbon were determined by $\mathrm{LECO}$ analysis at Exxon Production Research Company. Organic matter types (in \% of kerogen fraction) follow the classification scheme of Masran and Pocock (1981): $\mathrm{Am}=$ amorphous, $\mathrm{Al}=$ algal, $\mathrm{PS}=$ pollen and spores, $\mathrm{W}=$ woody, $\mathrm{C}=$ coaly, $\mathrm{IF}=$ indeterminate fines, $\mathrm{BT}=$ biodegraded terrestrial, $\mathrm{RB}$ pyrolysis yield is maximum (analyzed by Rock-Eval pyrolysis at Exxon Production Research Co.). Dash under any of the organic matter type columns indicates $0 \%$. Dash under other columns indicates no determination. 


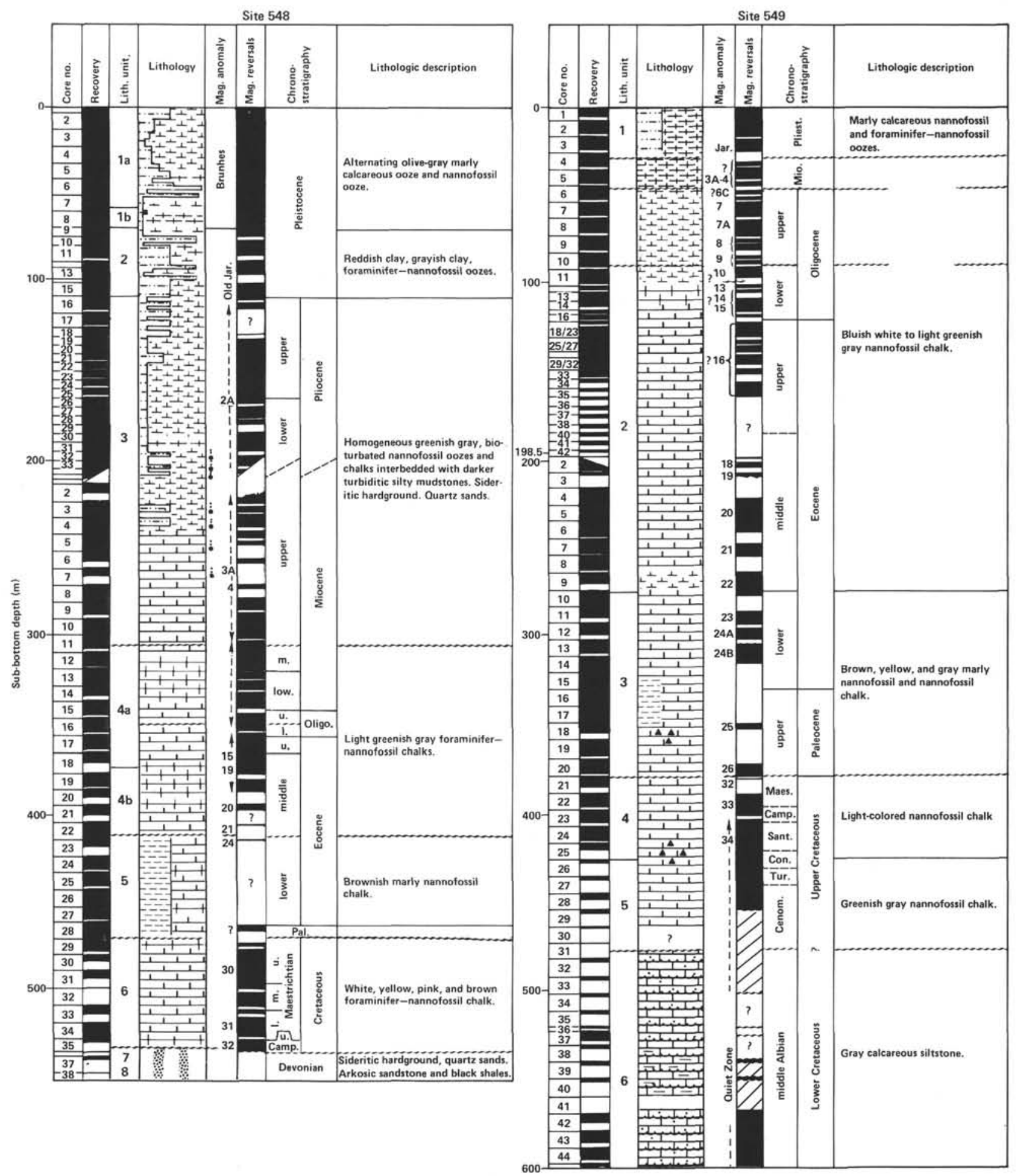

Figure 2. Lithologic and stratigraphic summary of DSDP Sites 548-551.

ter. On the basis of visual kerogen analysis, the proportion of marine organic matter (amorphous) averages $30 \%$ in these samples (Table 1). The bioturbated intervals with low content of organic material in Unit 5 contain mainly terrestrial $(90-100 \%)$ organic matter. The low TOC contents, terrestrial organic facies, and extensive bioturbation which characterize Units 1-4 are consistent with deposition under oxidizing bottom waters. Enrichment of marine organic matter in the black lami- nated mudstones of Unit 5 suggests that anoxic conditions occurred periodically during this time.

\section{Site 551}

Site 551 (3909 m water depth) lies at the seaward edge of the Goban Spur between Sites 550 and 549 (Fig. 1). The foraminifer-nannofossil oozes and chalks of Units $1-4$, Holocene to Turonian, have low contents of organic matter, with TOC values averaging $0.04-0.23 \%$ (Fig. 

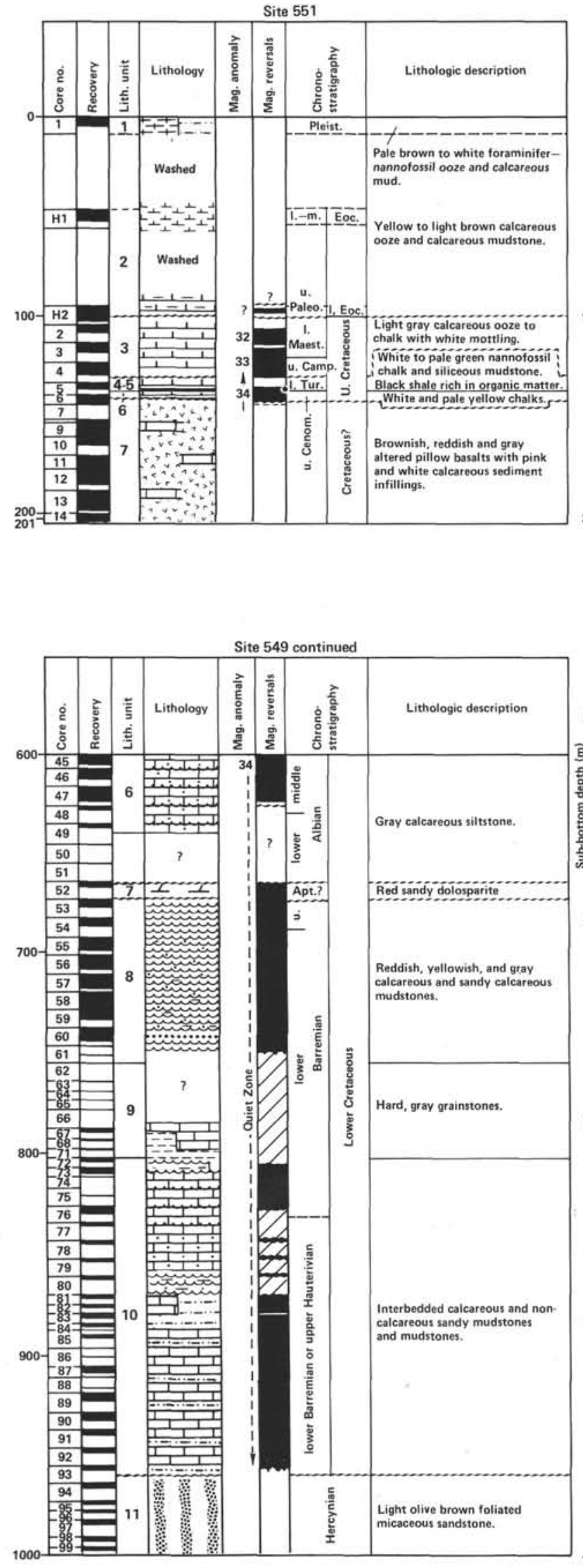

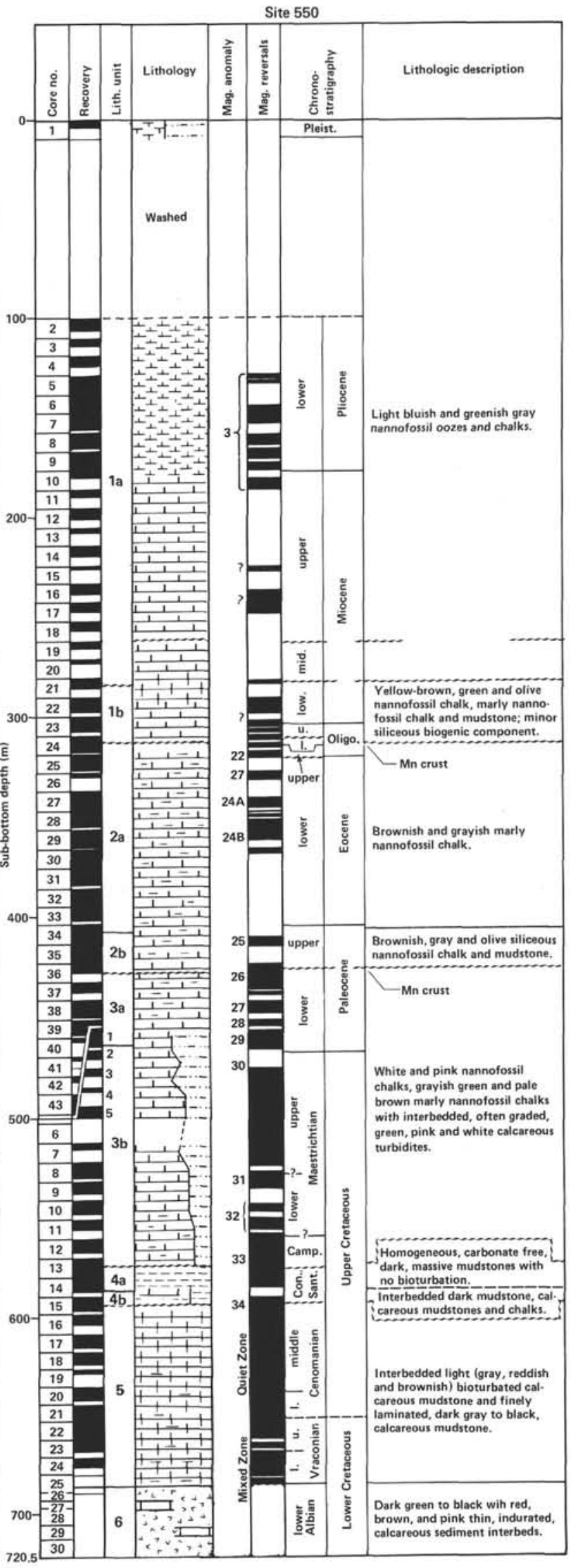

Figure 2. (Continued). 


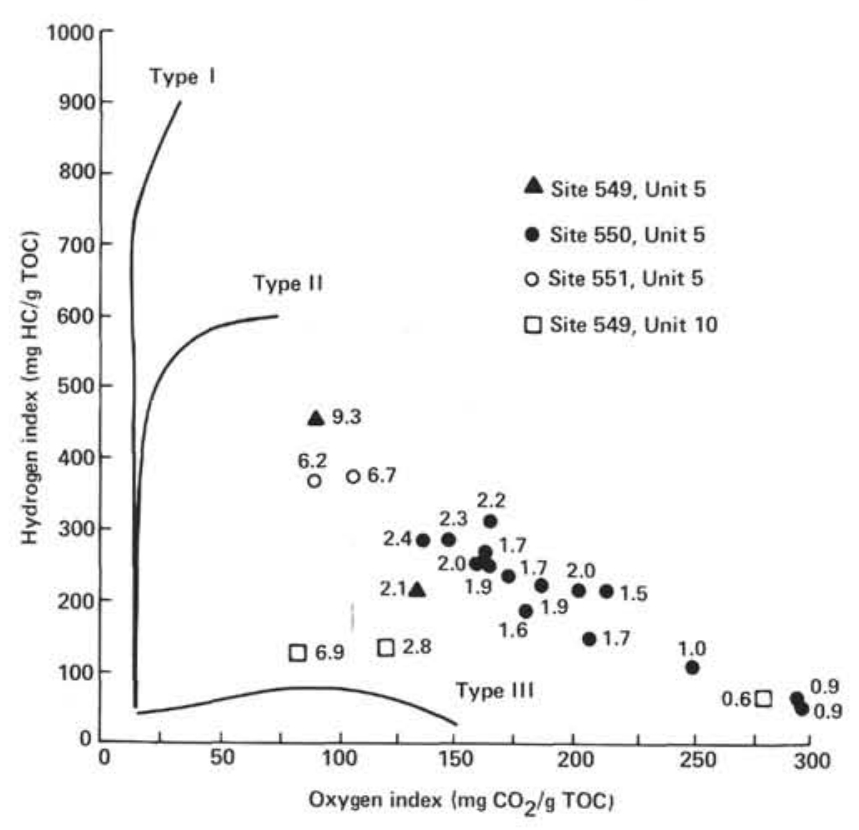

Figure 3. Characterization of organic matter by Rock-Eval pyrolysis. TOC values for samples as indicated.

2; Table 1). Chalks depleted in organic matter (av. $0.05 \%$ TOC) also occur in Unit 6 (upper Cenomanian). In sharp contrast with these units, however, a lower Turonian black mudstone rich in organic matter makes up Unit 5 (Fig. 2; Table 1). TOC values reach $10.94 \%$ in this unit (Waples and Cunningham, this volume), which also contains less than $5 \% \mathrm{CaCO}_{3}$ and is rich in biogenic silica and zeolites (de Graciansky et al., this volume). Hydrogen indices for Unit 5 average $366 \mathrm{mg} \mathrm{HC} / \mathrm{g}$ TOC, suggesting a mixed marine-terrestrial organic facies (Fig. 3 ). This was supported by kerogen description, which showed that about $30 \%$ of the organic matter is amorphous (probably marine) and another $30 \%$ is terrestrial (woody, coaly). The remaining $40 \%$ of the kerogen is indeterminate fine material. The preservation of labile components and the presence of laminations and biogenic siliceous material suggest that this unit was deposited under anoxic conditions associated with high productivity.

\section{Thermal Alteration}

Thermal alteration indices (TAI) measured from spore and pollen color (Staplin, 1969) indicate that the sediments cored on Leg 80 are thermally immature for the generation of hydrocarbons (Table 1). TAI values range from 1.5 to 2.3 ; values greater than 2.0 occur in the bottom units at all the sites.

The immaturity of the sediments is also shown by their low pyrolysis $T_{\max }$ values (Table 1). $T_{\max }$ is the experimental temperature at which the production of hydrocarbons during pyrolysis reaches a maximum (Espitalié et al., 1977). Values in the range $400-435^{\circ} \mathrm{C}$ indicate thermally immature kerogen, whereas the range $435-460^{\circ} \mathrm{C}$ indicates the main zone of oil generation. All the Leg 80 samples fall in the immature range, with values of $430^{\circ} \mathrm{C}$ or less.

\section{$\mathrm{C}_{15+}$ Data}

Four black laminated mudstone intervals, rich in organic matter, from Unit 5 at Sites 549,550 , and 551, and a bioturbated marly chalk, low in content of organic matter, also from Unit 5 at Site 550, were analyzed for components in the heavy $\mathrm{C}_{15}$ + extractable bitumen fraction (Table 2). Because of the small size of these samples, only two from Hole 550B (Sections 17-2 and 23-4) provided enough extract for main-group analysis. Asphaltene and pentane-soluble NSO compounds make up the bulk of the extract in these samples; hydrocarbons constitute less than $10 \%$, which is typical for thermally immature sediments (McIver, 1973).

Capillary gas chromatograms of the saturated-hydrocarbon fractions of Samples 550B-17-2, 103-112 cm and 550B-23-4, 57-72 cm are similar, with $n$-alkanes increasing in relative abundance from $n \mathrm{C}_{17}$ to $n \mathrm{C}_{23}$ and then decreasing abruptly in the $n \mathrm{C}_{24}-n \mathrm{C}_{35}$ range (Figs. 4A, B). The steroid/pentacyclic triterpenoid hydrocarbons in the $n \mathrm{C}_{27+}$ range are poorly represented. The only differences between the two samples are three major peaks in the $n \mathrm{C}_{19}-\mathrm{C}_{21}$ region of the chromatogram for the sample from Core 17, which do not appear in that from Core 23 (Figs. 4A, B). Although as yet unidentified, these peaks may represent olefinic, branched, or cyclic hydrocarbons which apparently were not buried or, more likely, were preserved in the deeper sample from Hole 550B. The marly chalk of the sample from Core 17 is finely laminated and rich in organic matter, whereas that from Core 23 has a low content of organic matter and is bioturbated; this suggests that bottom waters were anoxic during deposition of the Core $17 \mathrm{sam}$ ple and oxic during deposition of the Core 23 sample.

The $n$-alkane maximum in these chromatograms at $n \mathrm{C}_{23}$ is usually considered evidence of bacterial reworking of algal and terrestrial organic matter (Johnson and Calder, 1973; Galimov et al., 1982). The unimodal distribution of $n$-alkanes for the two Site 550B samples is skewed toward the light homologs $\left(<n \mathrm{C}_{20}\right)$, indicating that an algal component accompanies the material altered by microorganisms. Oddly, the $\mathrm{C}_{25}-\mathrm{C}_{31} n$-alkanes, indicative of terrestrial plant waxes (Eglinton and Hamilton, 1963), are lacking in these samples, despite visual kerogen and pyrolysis evidence for terrestrial input. Alteration during transport, however, may have reduced the extractable hydrocarbon component of the terrigenous organic fraction before deposition.

Table 2. Results of analyses of extractable bitumen $\left(\mathrm{C}_{15+}\right)$.

\begin{tabular}{|c|c|c|c|c|c|c|c|c|}
\hline \multirow{2}{*}{$\begin{array}{c}\text { Sample } \\
\text { (interval in } \mathrm{cm} \text { ) }\end{array}$} & \multirow{2}{*}{$\begin{array}{l}\text { TOC } \\
(\%)\end{array}$} & \multirow{2}{*}{$\begin{array}{l}\text { SOM } \\
(\mathrm{ppm})\end{array}$} & \multirow{2}{*}{$\begin{array}{c}\mathrm{HC} \\
(\mathrm{ppm})\end{array}$} & \multirow{2}{*}{$\begin{array}{c}\mathrm{HC} / \mathrm{TOC} \\
(\%)\end{array}$} & \multicolumn{4}{|c|}{$\begin{array}{c}\text { Components in SOM } \\
(\%)\end{array}$} \\
\hline & & & & & Sat & Aro & NSO & Asp \\
\hline $549-27$ & 9.31 & 3933 & - & - & - & - & - & 83.6 \\
\hline $550 \mathrm{~B}-17-2,1$ & 2.1 & 5 & 46 & 0.23 & 3.5 & 5.5 & 32.4 & 58.6 \\
\hline $550 \mathrm{~B}-18-1,41-45$ & 1.86 & 405 & - & - & - & - & - & 82.3 \\
\hline $550 \mathrm{~B}-23-4,57-72$ & 0.27 & 372 & 28 & 1.04 & 2.1 & 5.4 & 26.3 & 66.3 \\
\hline $551-5-2,67-70$ & 6.24 & 115 & - & - & - & - & - & 60.9 \\
\hline
\end{tabular}

Note: $\mathrm{SOM}=$ soluble organic matter (bitumen, $\mathrm{C}_{15+}$ ); $\mathrm{HC}=$ hydrocarbons; $\mathrm{Sat}=$ saturated hydrocarbons; Aro = aromatic hydrocarbons; NSO $=\mathrm{N}, \mathrm{S}, \mathrm{O} \mathrm{com}$ pounds; Asp = asphaltenes. Dash means no determination. 

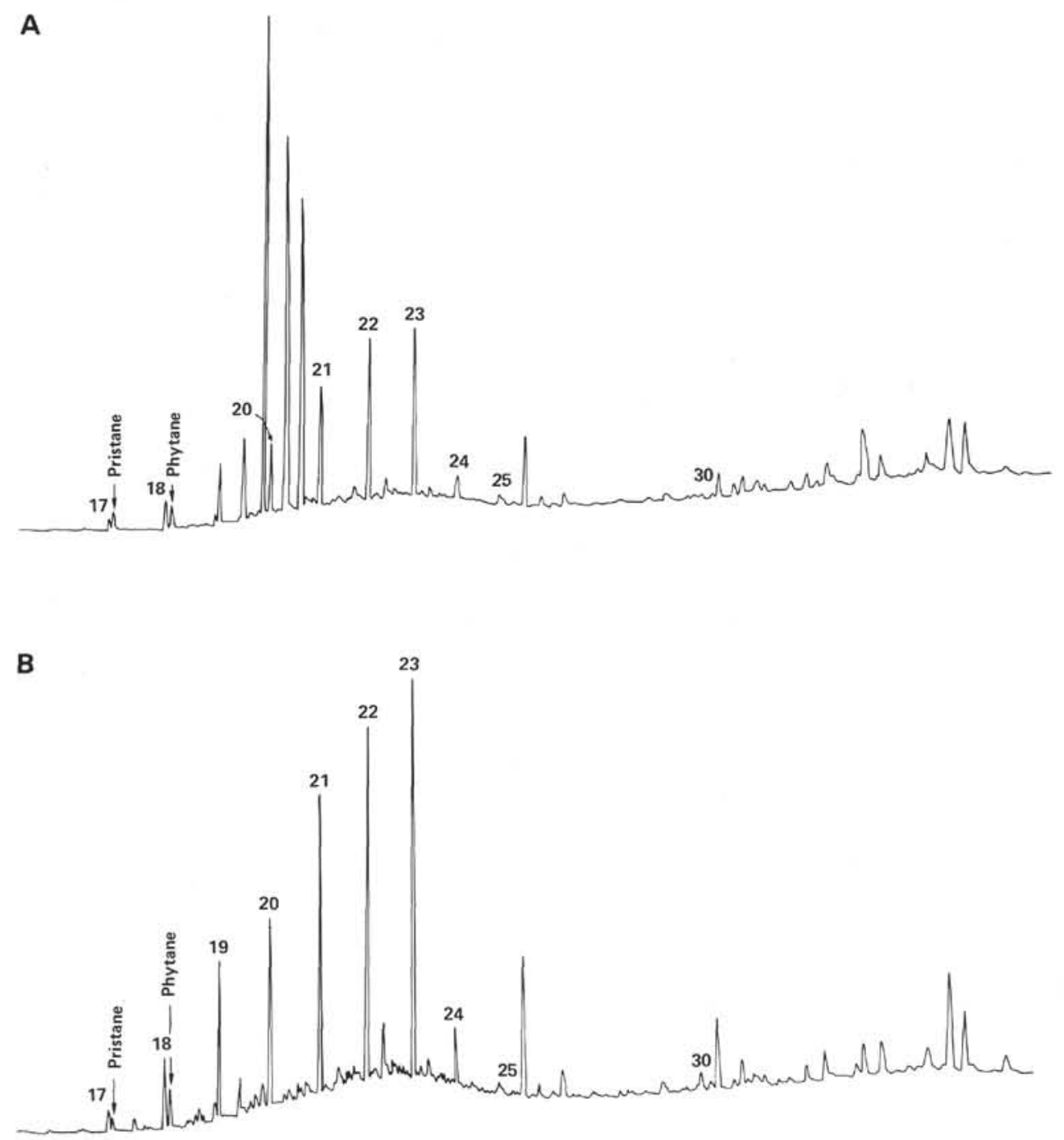

Figure 4. Gas chromatograms of the saturated $\mathrm{C}_{15}$ hydrocarbon fraction of (A) Sample 550B-17-2, $103-112 \mathrm{~cm}$, and (B) Sample 550B-23-4, 57-72 cm.

\section{DISCUSSION}

Two different periods of enhanced deposition of organic matter occurred in the mid-Cretaceous along the Goban Spur. At Site 550, the deposition of marly chalks with TOC values in excess of $2 \%$ took place during latest Albian (Vraconian) to middle Cenomanian time. Later, during the latest Cenomanian to Turonian at the shallower and more landward Sites 549 and 551, sediments were deposited which have markedly higher contents of organic matter (about 10\%) and a lithology (siliceous, noncalcareous mudstones) different from those laid down during the earlier period (Table 1).

\section{Latest Albian (Vraconian)-Cenomanian at Site $\mathbf{5 5 0}$}

\section{History of Enrichment in Organic Matter}

The record of enrichment in organic matter at Site 550 began with the initiation of sedimentation there in the late Albian after seafloor spreading had started. The first unit deposited, Unit 5 (Cores 550B-25 to 550B-15), consists of a $90-\mathrm{m}$ sequence of marly nannofossil chalks and calcareous mudstones, alternately dark, laminated, and rich in organic matter and light, bioturbated, and low in content of organic matter (Fig. 2). TOC values reach maxima of about $2 \%$ in Cores $16-18$ and $23-25$, but fall below $1 \%$ in the intervening cores (de Graciansky et al., this volume). A middle Cenomanian hiatus in Section 550B-15-4 separates these sediments from overlying Santonian-Coniacian claystones.

An example of the light and dark cycles as they occur in the upper part of Unit 5, from Section 550B-17-1 to Section 550B-18-1, is shown in Figure 5. In a typical cycle (Sample 550B-18-1, 35-113 cm), the contact between light gray (N5-N7, 5Y 6/1-7/1) chalk above and dark gray to black (5Y $2 / 1-4 / 1$ to N2-N3) finely laminated marly chalk below may be sharp to gradational, whereas the inverse contact is always gradational. Therefore, we interpret the base of the light-colored intervals as the beginning of a new cycle (Fig. 5). Given the relatively rapid sediment accumulation rate for this unit, about $13 \mathrm{~m}$ / $\mathrm{Ma}$, the thicknesses of these cycles yield periods of from 10,000 to 100,000 years. This range is commonly reported for cyclically deposited black shale sequences else- 

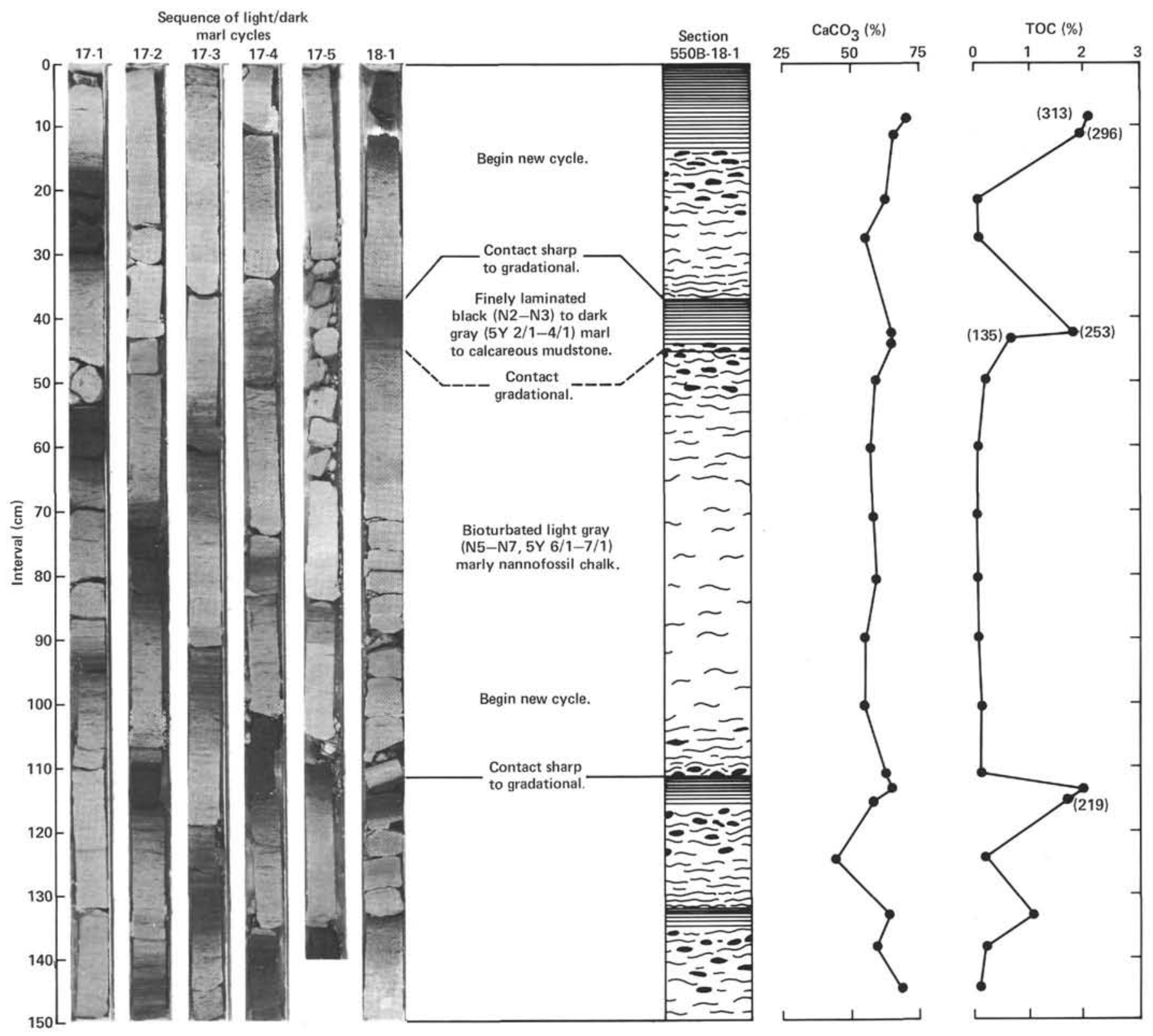

Figure 5. An example of the Albian-Cenomanian light/dark depositional cycles, Hole 550B. Variations in lithology, $\mathrm{TOC}$, and $\mathrm{CaCO}_{3}$ are shown for Section 550B-18-1. Hydrogen indices given in parentheses at right side of figure.

where in the North Atlantic (Dean et al., 1978; McCave, 1979; Arthur, 1979).

Overall, Unit 5 is approximately homogeneous with respect to lithologic composition, but several mineralogic trends are apparent. A gradual increase in carbonate content from 50 to $80 \% \mathrm{CaCO}_{3}$ occurs from the bottom to the top of the unit (Table 1; Waples and Cunningham, this volume). Also, a decrease in detrital quartz content and a transition in clay-mineral compositionfrom a mixture of smectite, illite, chlorite, and mixedlayer clay to nearly pure smectite-occurs upsection through Unit 5 (de Granciansky and Gillot, this volume).

Superimposed on these trends are minor short-term variations in $\mathrm{CaCO}_{3}$ content within the individual light/ dark cycles. In several cycles, the $\mathrm{CaCO}_{3}$ content was found to increase with TOC in the finely laminated intervals as compared with the bounding bioturbated intervals (Fig. 5; Waples and Cunningham, this volume, their fig. 8). TOC values are highest in the center of the laminated intervals (up to $2.4 \%$ TOC), and decrease to background values of about $0.1 \%$ TOC in the lightercolored portions of the bioturbated intervals. As shown for Section 550B-18-1, $\mathrm{CaCO}_{3}$ content parallels TOC, reaching values of $60-70 \%$ in the laminated intervals rich in organic matter and falling to baseline values of about $55 \%$ in the bioturbated intervals poor in organic matter (Fig. 5). There is a good positive correlation between the $\mathrm{CaCO}_{3}$ contents and TOC contents for several of the laminated intervals with high contents of organic matter throughout Unit 5 (Figure 6). $\mathrm{CaCO}_{3}$ and TOC contents are plotted as their ratios to the clastic fraction 


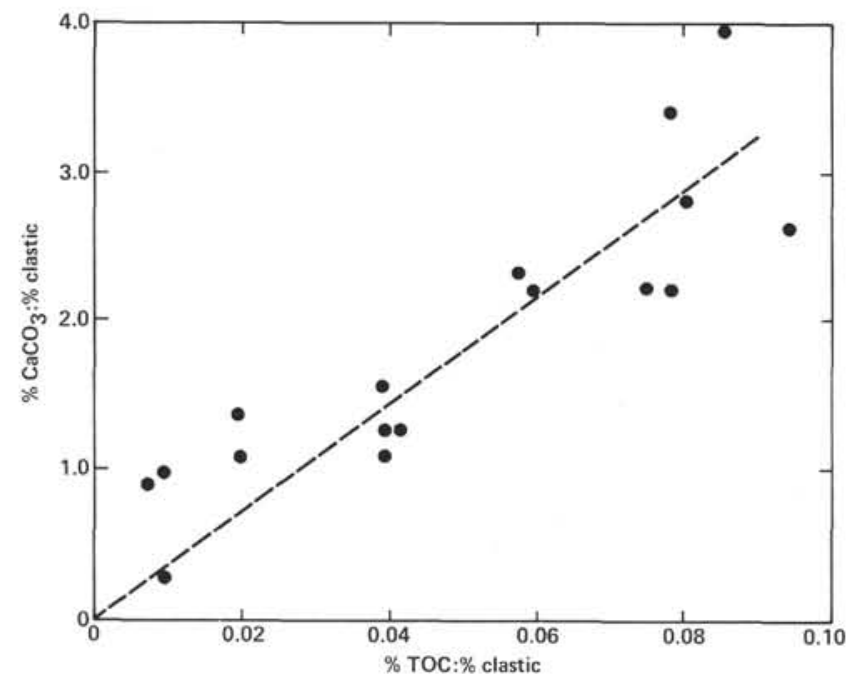

Figure 6. Covariance of $\% \mathrm{CaCO}_{3}: \%$ clastic and $\%$ TOC: $\%$ clastic for several of the laminated intervals rich in organic matter in Unit 5 , Site 550 .

to eliminate the effect of mutual dilution by this sedimentary component. The covariance of $\mathrm{CaCO}_{3}$ and TOC contents may be attributed to their joint production by biological activity in the surface waters.

Several factors argue against sediment redeposition as the cause of cyclic sedimentation in Unit 5 at Site 550. These include the gradualness of the mineralogic trends, gradational nature of contacts between light and dark intervals (except for the contacts at the tops of the dark intervals, which may be sharp), and the lack of graded bedding and current laminations. Instead of sediment redeposition, cyclic variation in preservational conditions - the degree of oxygenation of the bottom waters-possibly coupled with or related to changes in surface-water productivity, may have led to the bedding rhythms.

\section{Evolution of Organic Facies}

The relative amounts of marine and terrestrial organic matter in sediments depend on the differential rates at which these components accumulate compared with carbonate and clastic diluents. Source functions controlling the accumulation rate of marine material include the rate of primary productivity in the surface waters and the competing rate of decomposition of organic matter in the water column and sediments. Only if the former rate outweighs the latter, as in areas of anoxic bottom waters and (or) high productivity, will marine organic matter be buried. The accumulation rate of terrestrial organic matter is somewhat less influenced by the rate of organic decomposition, owing to greater resistance of terrestrial plant remains to oxidation. Other factors, such as terrestrial productivity and runoff, both of which are climatically controlled, are important modulators of the terrestrial TOC flux.

For Unit 5 at Site 550, the controls on organic facies were determined by examining variations in the accumulation rates of the major organic and lithologic constituents (Fig. 7). The accumulation rates were calculated by multiplying the concentrations of the various sedimentary constituents (from Table 1) by the bulk accumulation rate, using the relationship of Muller and Suess (1979) and Thiede et al. (1982). Accumulation rates de-

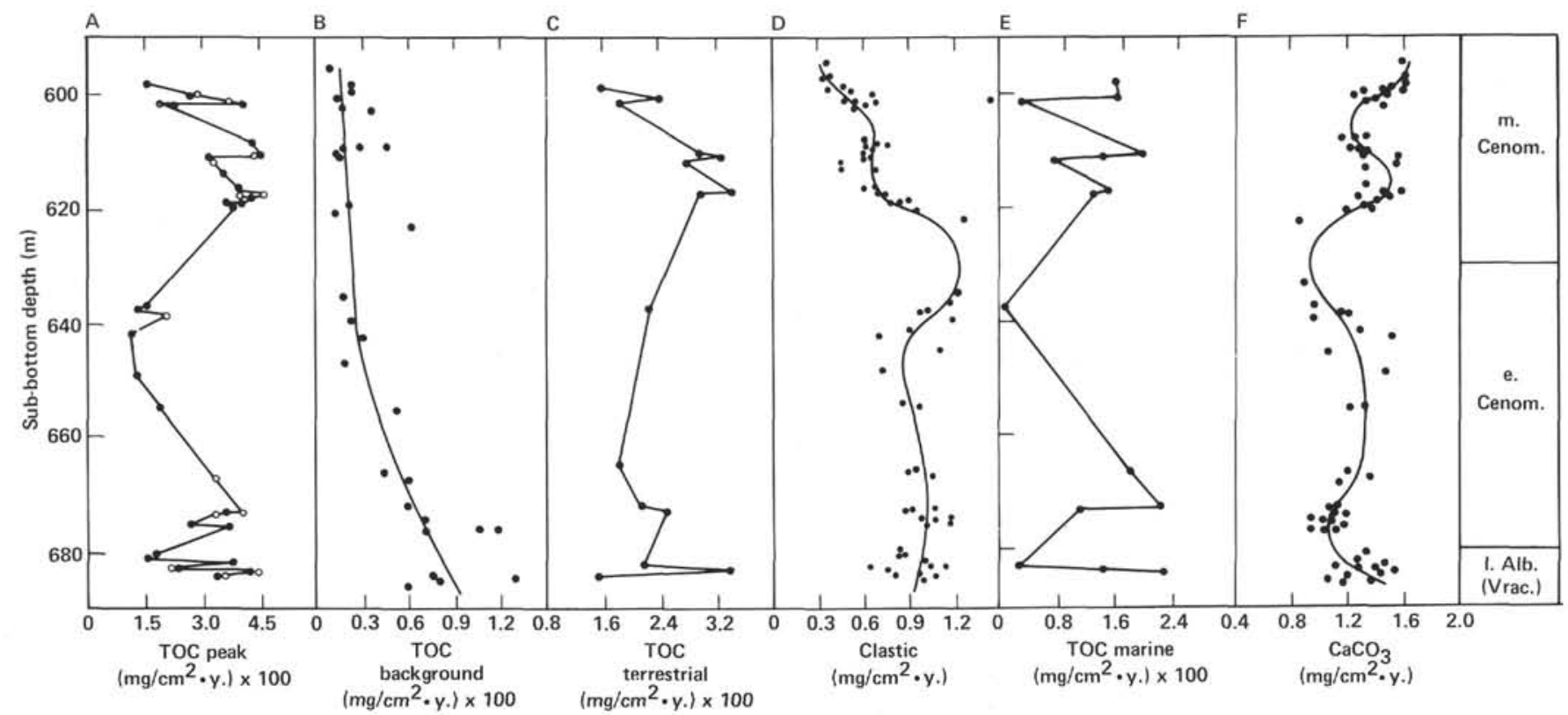

Figure 7. Downhole rates of accumulation for the major organic and lithology constituents (identified on figure) of Unit 5, Site 550. Calculated by using a sedimentation rate of $13 \mathrm{~m} / \mathrm{m}$.y., an average porosity of $30 \%$, and an average density of $2.6 \mathrm{~g} / \mathrm{cm}^{3}$ (de Graciansky et al., this volume). TOC, carbonate, and clastic (non-carbonate) data from this study and Waples and Cunningham (this volume) were used to calculate the respective accumulation rates. TOC accumulation rates are bimodally distributed, with one population (A) above $1 \mathrm{mg} / \mathrm{cm}^{2} \cdot \mathrm{y} . \times 100$ ("peak rate") and another (B) below that value ("background rate"). Peak TOC accumulation rate is further divided into (C) terrestrial TOC and (E) marine TOC accumulation rates, using organic facies data from this study. 
rived in this manner may be related directly to the individual source functions which control organic and inorganic sedimentation.

Since bottom waters alternated between oxidizing and anoxic conditions during the deposition of Unit 5 , the rates of TOC accumulation shifted between peak and background levels, respectively, under these drastically different conditions of preservation. We considered peak TOC values to be those greater than $0.8 \%$. The pattern of peak rate of accumulation of TOC is rather unsteady, showing maxima of about $4.5 \times 10^{-2}$ $\mathrm{mg} / \mathrm{cm}^{2} \cdot \mathrm{y}$. in the latest Albian and middle Cenomanian and a pronounced minimum of about $1.5 \times 10^{-2}$ $\mathrm{mg} / \mathrm{cm}^{2} \cdot$ y. in the early Cenomanian (Fig. 7A). Background rates of TOC accumulation scatter around a mean which decreases gradually from about $9 \times 10^{-3}$ $\mathrm{mg} / \mathrm{cm}^{2} \cdot \mathrm{y}$. in the latest Albian to $3 \times 10^{-3} \mathrm{mg} / \mathrm{cm}^{2} \cdot \mathrm{y}$. in the middle Cenomanian (Fig. 7B). These peak and background rates of organic carbon accumulation are comparable to those of typical low-productivity regions in the modern ocean (Muller and Suess, 1979).

The flux of terrestrial TOC makes up the bulk of the peak TOC accumulation rate in Unit 5 and determines its general pattern (Fig. 7C). Terrestrial organic matter is probably transported to the deep sea by mechanisms similar to those responsible for clastic transport, such as by turbidity currents or in suspension in the slow-moving, near-bottom nepheloid layer (Summerhayes, 1981). For certain terrestrial components, such as pollen and spores, aeolian transport may also be important (Simoneit and Eglinton, 1977). Therefore, we should expect to see a positive relationship between the accumulation rates of terrestrial organic matter and clastic material. In a crossplot of the variables, however, two significant correlations emerge (Fig. 8A). The trend with the lower slope corresponds to lower Cenomanian to uppermost Albian samples from deeper than about $630 \mathrm{~m}$ sub-bottom, and shallower middle Cenomanian samples form the trend with the greater slope.

The sudden increase in the ratio of the terrestrial TOC to clastic flux beginning in the early middle Cenomanian may be related to the eustatic rise of sea level toward a high stand (Fig. 9) in the middle Cenomanian (Vail et al., 1977). A decline in clastic input is recorded upsection through Unit 5, reflecting the increasing distance between this site and the shoreline as sea level rose (Fig. 7D). A decrease in the rate of TOC accumulation under oxidizing conditions (background values) is also evident toward the top of Unit 5 (Fig. 7B). Sediments with background TOC values $(<0.8 \%)$ generally contain only terrestrially derived woody and coaly kerogen. Good correlation of the background TOC and clastic fluxes suggests similar modes of transport and proportional rates of supply for both components (Fig. 8B). The peak TOC flux, however, is modified by differential preservation. In the earliest Cenomanian and early middle Cenomonian, when conditions of preservation were optimal at this site, the terrestrial component of the peak TOC flux reached similar maxima of about $3 \times$ $10^{-2} \mathrm{mg} / \mathrm{cm}^{2}$ - y. (Fig. 7C). Because of the steady decrease in clastic flux recorded upsection, however, the ratio of terrestrial TOC to clastic accumulation rate is higher for the later period of oxygen depletion.

The accumulation rate for the marine component of the peak TOC is more erratic than that for the terrestrial component (Fig. 7E). High marine TOC input in the earliest and early middle Cenomanian boosts the peak TOC flux to its highest rates in the period represented by

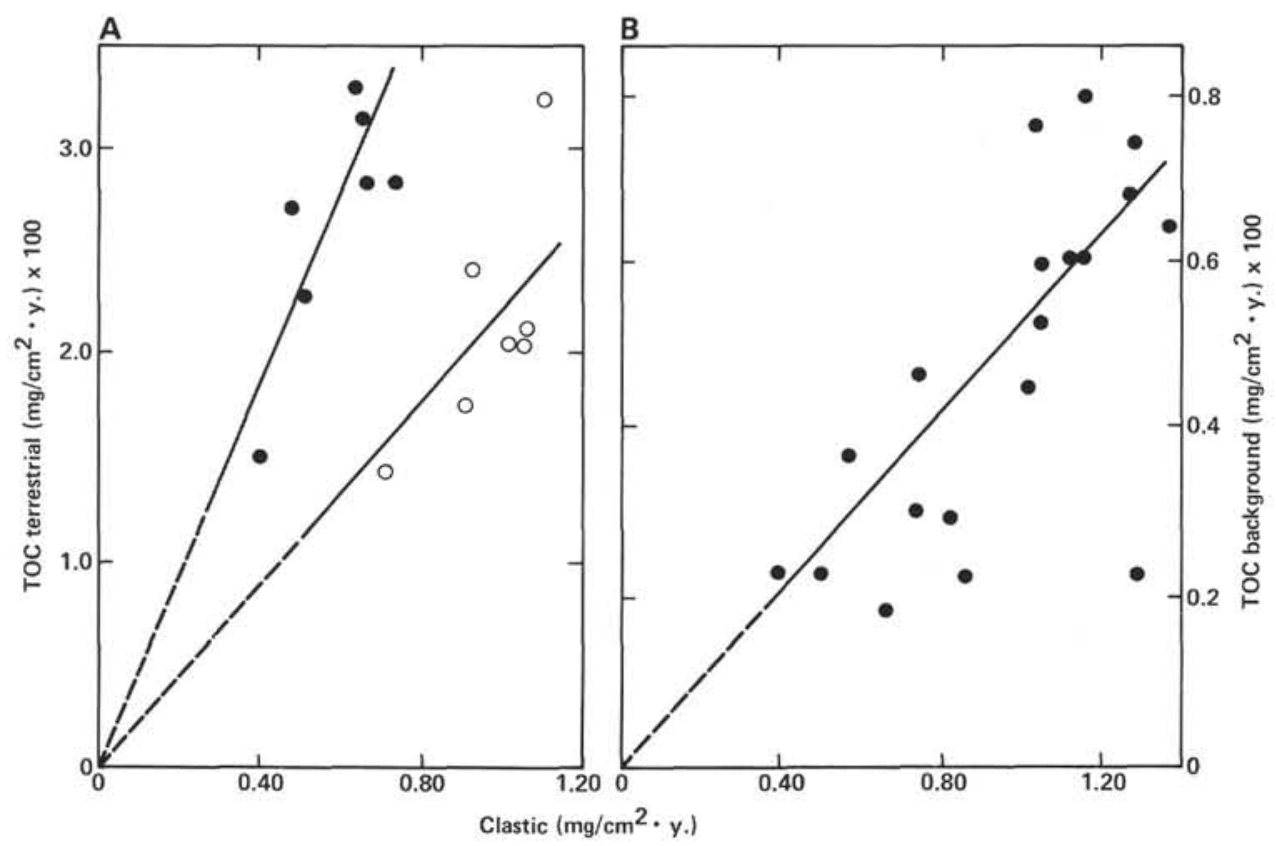

Figure 8. A. Interdependence of the accumulation rates of clastic material and the terrestrial component of peak TOC for Unit 5, Site 550 . Filled circles correspond to samples from depths shallower than $630 \mathrm{~m}$ sub-bottom, and open circles correspond to samples from depths greater than $630 \mathrm{~m}$. B. Interdependence of the accumulation of rates of clastic material and background TOC (Unit 5, Site 550). 


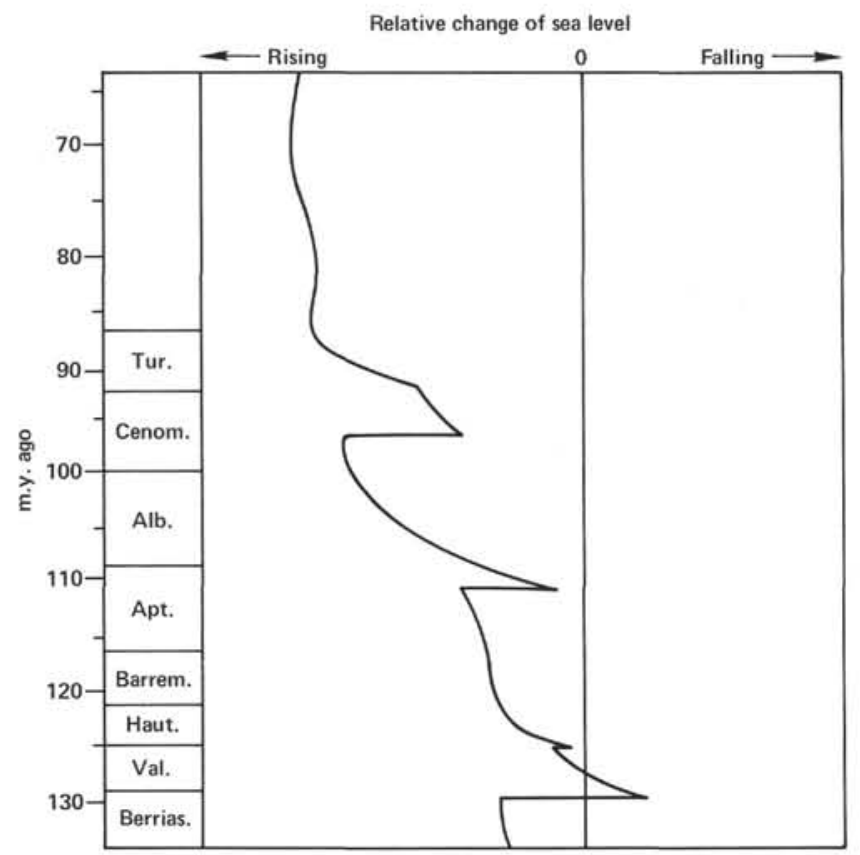

Figure 9. Relative changes of sea level in the Cretaceous (based on Vail et al., 1977).

Unit 5, and approximate parity between marine and terrestrial components in the sediments is achieved. Minimum rates of marine TOC accumulation, less than $8 \times$ $10^{-3} \mathrm{mg} / \mathrm{cm}^{2} \cdot \mathrm{y}$, are recorded in several of the laminated intervals rich in organic matter, and are probably a function of decreased productivity and preservation. Declines in productivity are suggested by the minima in the $\mathrm{CaCO}_{3}$ accumulation rate, which correlate with minima in the marine TOC flux (Fig. 7F). The peak minimum in the marine TOC flux, represented at about $640 \mathrm{~m}$ sub-bottom, occurred when stronger oxidizing conditions existed at this site in the early Cenomanian (de Graciansky et al., this volume).

\section{Cenomanian-Turonian at Sites 549 and 551}

This horizon is associated with drilling breccia at both sites, so that bedding relationships and upper and lower contacts with chalks low in content of organic matter are obscured. However, intact fragments indicate finely laminated textures in which biogenic siliceous material, zeolites, pyrite, and organic matter make up the laminae (de Graciansky et al., this volume). Carbonate contents are generally less than $20.0 \% \mathrm{CaCO}_{3}$, and TOC contents reach values of about $10 \%$ at Sites 549 and 551 (Table 1; Waples and Cunningham, this volume). The organic facies of this horizon shows a marine predominance not evident for the earlier period of enrichment in organic matter at Site 550. The depths of Sites 549 and 551 during deposition of the upper Cenomanian to lower Turonian sediments were about 1500 and $2000 \mathrm{~m}$, respectively (de Graciansky et al., this volume). This places them at intermediate depths; possibly within an expanded oxygen-minimum layer existing at the time (Waples and Cunningham, this volume). The relatively high content of biogenic silica (mainly recrys- tallized radiolarian tests) in the laminated mudstones rich in organic material suggests that intensification of the oxygen minimum by a high-productivity event may have led to bottom-water anoxia at these sites.

Because of uncertainty in the overall sediment accumulation rates for the black laminated mudstones at both sites, accumulation rates of their organic matter were not determined. Sediment accumulation rates for similar upper Cenomanian to Turonian black mudstones at other North Atlantic DSDP sites (de Graciansky et al., 1982) were unusually low (less than $1 \mathrm{~m} / \mathrm{m}$.y.). The low sediment accumulation rates were in part caused by the reduced carbonate input consequent upon the relatively shallow CCD which existed at the time (Thierstein, 1979; de Graciansky et al., this volume). Also, the high eustatic sea level (Fig. 9) may have caused the rate of clastic influx to diminish (de Graciansky et al., 1982; Herbin and Deroo, 1982). Therefore, marine organic matter and associated biogenic siliceous material probably produced during coastal upwelling along the Goban Spur accumulated in these sediments little diluted by biogenic carbonate and clastic debris.

\section{Regional Implications}

The coring along the Goban Spur of mid-Cretaceous sediments rich in marine organic matter necessitates reconsideration of the paleoenvironmental models for the northern North Atlantic. Dark shales high in content of organic matter have been recovered from the mid-Cretaceous sections of other DSDP sites in this region, including Site 398 along the Vigo Seamount and Sites 400 and 402 along the Biscay Margin (de Graciansky et al., 1979; Deroo et al., 1979a; Arthur, 1979). Because of the presence of marine organic matter (Deroo et al., 1979a; Summerhayes, 1981) and laminated fabrics in the upper Albian to Cenomanian black shale intervals at Site 398, Arthur (1979) suggests that near-anoxic conditions occurred periodically in the deep-water mass. At Site 550, coeval laminated marly chalks rich in organic matter indicate that anoxic conditions also existed periodically along the northern Biscay Margin at bathyal depths. At Sites 400 and 402 , however, the organic facies of the Aptian to upper Albian black shales is predominantly terrestrial (Deroo et al., 1979b). This prompted de Graciansky et al. (1979) and Roberts and Montadert (1979) to suggest that oxidizing conditions existed from shelf to abyssal depths in the Bay of Biscay.

Since intervals rich in organic matter make up only a minor fraction of the entire upper Albian to middle Cenomanian section at Site 550, bottom waters appear to have been predominantly oxidizing. The dark laminated bands represent relatively brief periods (about $10,000 \mathrm{y}$.) of anoxic or near-anoxic conditions. Oxygenated bottom waters may periodically become oxygen depleted by climatically induced increases in productivity (Dean et al., 1978; Gardner et al., 1978). When increased productivity raises the rate of supply of organic matter to the sediments, oxygen consumption by organic decomposition may exceed oxygen supply by deep currents. This can cause bottom waters to become depleted in oxygen (Gardner et al., 1978). If productivity declines, the re- 
dox boundary may return to a position at or below the sediment water interface, either gradually or abruptly, depending on the rate of renewal of oxygen by deep currents. As noted previously, the covariance of TOC and $\mathrm{CaCO}_{3}$ contents in many of the bands suggests that variations in marine productivity controlled their occurrence. In areas of lower productivity yet higher influx of terrestrial material including organic matter, as probably at Sites 400 and 402 (de Graciansky et al., 1979) and Site 398 (Arthur, 1979), oxygen depletion may have existed only in the sediments, with near-anoxic conditions occurring occasionally in the bottom waters.

The Cenomanian-Turonian siliceous mudstones enriched in marine organic matter at Sites 549 and 551 appear to have been deposited in conjunction with a significant oceanographic event which enhanced the deposition of marine organic matter over most of the North Atlantic (Tissot et al., 1980; Summerhayes, 1981; de Graciansky et al., 1982; Herbin and Deroo, 1982). A relatively sudden increase in oceanwide organic carbon production, related to increased circulation between North and South Atlantic in the late Cenomanian and (or) the increase in oceanic surface area resulting from the Cenomanian-Turonian transgression (Fig. 8), has been suggested as the cause of the excessive organic enrichment (McCave, 1979; Tucholke and Vogt, 1979; Arthur and Natland, 1979; Schlanger and Jenkyns, 1976; Summerhayes, 1981). The widespread anoxia associated with the event may have resulted from the combination of an increased oxygen deficit in the deep-water mass and an expanded mid-water oxygen minimum apparently caused by the increased supply of marine organic matter to the sediments (Schlanger and Jenkyns, 1976; McCave, 1979).

\section{CONCLUSIONS}

1. The Cenozoic and Lower and Upper Cretaceous sediments along the Goban Spur generally have low contents of organic matter and contain a terrestrial organic facies. They are also extensively bioturbated, indicating that deposition took place under oxidizing conditions.

2. Mid-Cretaceous black marly chalk and mudstone intervals at Sites 549-551 are enriched in organic matter. The sediments are finely laminated and contain marine organic matter, which implies deposition under oxygendepleted bottom waters.

3. In the uppermost Albian (Vraconian) to middle Cenomanian section at Site 550, light-colored, bioturbated, marly chalks low in content of organic matter alternate rhythmically with dark, finely laminated, marly chalks and calcareous mudstones rich in organic matter. Periodicities of the cycles range from 10,000 to 100,000 y. Climatically induced variations in productivity and circulation caused the bottom waters at this site to alternate between oxia and anoxia. Elsewhere in the northern North Atlantic where productivities remained low, as at nearby Sites 400 and 402 , bottom waters were oxidizing.

4. An upper Cenomanian-Turonian black mudstone interval, rich in marine organic matter and biogenic siliceous material, was deposited at mid-water depths at
Sites 549 and 551. Its presence indicates that reducing conditions associated with upwelling and, probably, intensification and expansion of the oxygen-minimum layer, existed in this region. Coeval mudstones enriched in marine organic matter have been recovered at other DSDP sites throughout the North Atlantic. These sediments are attributed to an oceanwide high-productivity event spawned by the onset of circulation between the North and South Atlantic.

5. The high stand of eustatic sea level in the late $\mathrm{Ce}-$ nomanian-Turonian may have played a role in the concentration of organic matter in the sediments by lowering the accumulation rate of diluting mineral material.

\section{ACKNOWLEDGMENTS}

We thank Exxon Production Research Company for permission to publish this work. P. M. Kroopnick and E. C. Foo provided helpful comments on the ideas presented here. TOC analyses and Rock-Eval pyrolysis were carried out by M. S. Bisotooni and K. Hahn, respectively, both of Exxon Production Research Company.

\section{REFERENCES}

Arthur, M. A., 1979. North Atlantic Cretaceous black shales: the record at Site 398 and a brief comparison with other occurrences. In Ryan, W. B. F., Sibuet, J. C., et al., Init. Repts. DSDP, 47, Pt. 2: Washington (U.S. Govt. Printing Office), 719-751.

Arthur, M. A., and Natland, J. H., 1979. Carbonaceous sediments in the North and South Atlantic: the role of salinity in stable stratification of Early Cretaceous basins. In Talwani, M., Hay, W. W., and Ryan, W. B. F. (Eds.), Deep Drilling Results in the Atlantic: Continental Margins and Paleoenvironment: Washington (Am. Geophys. Union), Maurice Ewing Series, 3:375-401.

Dean, W. E., Gardner, J. V., Jansa, L. F., Cepek, P., and Seibold, E., 1978. Cyclic sedimentation along the continental margin of Northwest Africa, DSDP Leg 41. In Lancelot, Y., Siebold, E., et al., Init. Repts. DSDP, 41: Washington (U.S. Govt. Printing Office), 965-986.

de Graciansky, P. C., Auffret, G. A., Dupeuble, P., Montadert, L., and Müller, C., 1979. Interpretation of depositional environments of the Aptian/Albian black shales on the north margin of the Bay of Biscay (DSDP Sites 400 and 402). In Montadert, L., Roberts, D. G., et al., Init. Repts. DSDP, 48: Washington (U.S. Govt. Printing Office), 877-908.

de Graciansky, P. C., Brosse, E., Deroo, G., Herbin, J. P., Montadert, L., Müller, C., Sigal, J., and Schaaf, A., 1982. Les formations d'âge Crétacé de l'Atlantique Nord et leur matière organique: Paléogéographie et milieux de dépôt. Rev. Inst. Fr. Pet., 37:275-336.

Deroo, G., Herbin, J. P., Roucaché, J., and Tissot, B., 1979a. Organic geochemistry of Cretaceous shales from DSDP Site 398, Leg 47B, eastern North Atlantic. In Sibuet, J. C., Ryan, W. B. F., et al., Init. Repts. DSDP, 47, Pt. 2: Washington (U.S. Govt. Printing Office), 513-522.

1979b. Organic geochemistry of Cretaceous medstones and marly limestones from DSDP Sites 400 and 402, Leg 48, eastern North Atlantic. In Montadert, L., Roberts, D. G., et al., Init. Repts. DSDP, 48: Washington (U.S. Govt. Printing Office), 921-930.

Eglinton, G., and Hamilton, R. J., 1963. The distribution of alkanes. In Swain, T. (Ed.), Chemical Plant Taxonomy: New York (Academic Press), pp. 187-217.

Espitalié, J., Laporte, J. L., Madec, M., Marquis, F., Lepiat, P., Poulet, J., and Boutefeu, A., 1977. Rapid method for source rock characterization and for evaluating their petroleum potential and their degree of evolution. Rev. Inst. Fr. Pet., 32:3-40.

Galimov, E. M., Kodina, L. A., Bogacheva, M. P., and Shirinsky, V. G., 1982. Organic geochemical studies of samples from Deep Sea Drilling Project Leg 64, Gulf of California: Sites 474, 477, 478, 479, and 481. In Curray, J. R., Moore, D. G., et al., Init. Repts. DSDP, 64: Washington (U.S. Govt. Printing Office), 819-831.

Gardner, J. V., Dean, W. E., and Jansa, L., 1978. Sediments recovered from the northwest African continental margin, Leg 41, DSDP. In 
Lancelot, Y., Seibold, E., et al., Init. Repts. DSDP, 41: Washington (U.S. Govt. Printing Office), 1121-1134.

Herbin, J. P., and Deroo, G., 1982. Sédimentologie de la matière organique dans les formations du Mésozoïque de l'Atlantique Nord. Bull. Soc. Geol. France, 24:497-510.

Johnson, R. W., and Calder, J. A., 1973. Early diagenesis of fatty acids and hydrocarbons in a salt marsh environment. Geochim. Cosmochim. Acta, 37:1943-1955.

Masran, T. C., 1978. Deep North Atlantic Ocean-visual organic matter: Esso Resources Canada Ltd. [unpub. in-house rept.].

Masran, T. C., and Pocock, S. A. J., 1981. The classification of plantderived particular organic matter in sedimentary rocks. In Brooks, J. (Ed.), Organic Maturation Studies and Fossil Fuel Exploration: New York (Academic Press), pp. 145-159.

McCave, I. N., 1979. Depositional features of organic black and green mudstones at DSDP Sites 386 and 387, western North Atlantic. In Tucholke, B. E., Vogt, P. R., et al., Init. Repts. DSDP, 43: Washington (U.S. Govt. Printing Office), 411-416.

McIver, R. D., 1973. Geochemical significance of gas and gasolinerange hydrocarbons and other organic matter in a Miocene sample from Site 134-Balearic Abyssal Plain. In Ryan, W. B. F., Hsü, K. J., et al., Init. Repts. DSDP, 13, Pt. 2: Washington (U.S. Govt. Printing Office), 813-816.

Muller, P. J., and Suess, E., 1979. Productivity, sedimentation rate, and sedimentary organic matter in the oceans-1. Organic carbon preservation. Deep Sea Res., 26A:1347-1362.

Roberts, D. G., and Montadert, L., 1979. Margin paleoenvironments of the northeast Atlantic. In Montadert, L., Roberts, D. G., et al., Init. Repts. DSDP, 48: Washington (U.S. Govt. Printing Office), 1099-1118.

Schlanger, S. O., and Jenkyns, H. C., 1976. Cretaceous oceanic anoxic events: causes and consequences. Geol. Mijnbouw, 55:179-184.
Simoneit, B. R. T., and Eglinton, G., 1977. Organic matter of aeolian dust and its input to marine sediments. Adv. Org. Geochem. Proc. Int. Meet. 7th 1975, pp. 415-430.

Staplin, F. L., 1969. Sedimentary organic matter, organic metamorphism, and oil and gas occurrence. Can. Pet. Geol. Bull., 17: 47-66.

Summerhayes, C. P., 1981. Organic facies of middle Cretaceous black shales in deep North Atlantic. Am. Assoc. Pet. Geol. Bull., 65: 2364-2380.

Thiede, J., Suess, E., and Muller, P. J., 1982. Late Quaternary fluxes of major sediment components to the sea floor at the northwest African slope. In von Rad, U., Hinz, K., Sarnthein, M., and Seibold, E. (Eds.), Geology of the Northwest African Continental Margin: Berlin (Springer-Verlag), pp. 605-631.

Thierstein, H. R., and Berger, W. H., 1978. Injection events in ocean history. Nature, 276:461-466.

Tissot, B., Demaison, G., Masson, P., Delteil, J. R., and Combaz, A., 1980. Paleoenvironment and petroleum potential of middle Cretaceous black shales in Atlantic basins. Am. Assoc. Pet. Geol. Bull., 64:2051-2063.

Tucholke, B. E., and Vogt, P. R., 1979. Western North Atlantic: sedimentary evolution and aspects of tectonic history. In Tucholke, B. E., Vogt, P. R., et al., Init. Repts. DSDP, 43: Washington (U.S. Govt. Printing Office), 791-825.

Vail, P. R., Mitchum, R. M., and Thompson, S., 1977. Global cycles of relative changes of sea level, in seismic stratigraphy. Mem. Am. Assoc. Pet. Geol., 26:83-98.

Date of Initial Receipt: February 28, 1983

Date of Acceptance: May 12, 1983 